\title{
KNOWLEDGE AND USE OF ERGONOMIC PRINCIPLES IN PHYSICIANS AND NURSES WITH LOW BACK PAIN
}

\section{WIEDZA ORAZ ZASTOSOWANIE ZASAD ERGONOMII PRZEZ LEKARZY I PIELĘGNIARKI Z DOLEGLIWOŚCIAMI BÓLOWYMI KRĘGOSŁUPA}

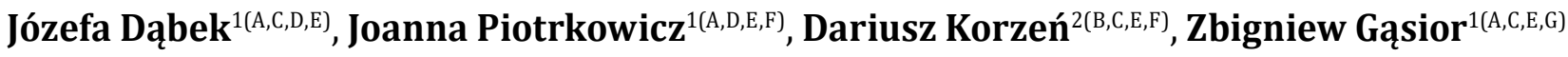

${ }^{1}$ Department of Cardiology, School of Health Science in Katowice, Medical University of Silesia, Katowice, Poland ${ }^{2}$ Department of Anaesthesiology and Intensive Care, The Municipal Hospital in Ruda Śląska, Poland

Authors' contribution Wkład autorów:

A. Study design/planning zaplanowanie badań

B. Data collection/entry zebranie danych

C. Data analysis/statistics dane - analiza i statystyki D. Data interpretation interpretacja danych E. Preparation of manuscript przygotowanie artykułu F. Literature analysis/search wyszukiwanie $\mathrm{i}$ analiza literatury G. Funds collection zebranie funduszy
Tables: 5

Figures: 2

References: 18

Submitted: 2018 Dec 10

Accepted: 2019 Jan 11

\section{Summary}

Background. Medical professionals frequently experience low back pain as a result of mechanical overload caused by prolonged standing, performing activities in a position of trunk flexion, extended work hours and physically stressful duties. The above-mentioned stresses, when they exceed the adaptive capacity of the tissues, can lead to pain, degenerative changes and even disability. Material and methods. 114 employees, including 48 (42\%) physicians and $66(58 \%)$ nurses, were examined. Their average age was $42.08 \pm 9.43$ years, and the average years of work experience was $17.16 \pm 10.36$ years. To assess the occurrence of low back pain, a standardized Oswestry Questionnaire was used, while for assessments of ergonomics an original questionnaire was used. Results. 95 respondents (83.33\%), including 31 physicians $(64.58 \%)$ and 64 nurses (96.96\%), did not apply the principles of ergonomics in the work environment. The most common reasons were that working conditions were not conducive to ergonomic approaches to their duties and that there were not enough medical personnel to make ergonomic choices possible. All subjects experienced back pain. The Oswestry Questionnaire was used to determine the degree of disability caused by back pain. Among the physicians, the majority of respondents ( $\mathrm{n}=35,73 \%)$ experienced a small degree of disability, while the nurses experienced a moderate amount of disability $(n=35,53 \%)$. Conclusions. Most of the examined personnel did not apply principles of ergonomics and had incomplete knowledge in this area. All subjects were burdened with low back pain, one of every ten of them were seriously affected. The results indicate the need to provide ergonomics education to medical personnel.

Keywords: ergonomics, low back pain, Oswestry Questionnaire

\section{Streszczenie}

Wprowadzenie. Pracownicy personelu medycznego narażeni sa na wystepowanie dolegliwości bólowych kręgosłupa w wyniku przeciążeń mechanicznych układu ruchu spowodowanych długotrwałym przebywaniem w pozycji stojącej, wykonywaniem czynności zawodowych w pozycji zgięcia tułowia oraz długimi godzinami pracy i dyżurami. Wymienione przeciążenia przekraczające zdolności adaptacyjne tkanek, prowadzą do występowania dolegliwości bólowych, zmian zwyrodnieniowych, a nawet do niepełnosprawności. Materiał i metody. Zbadano 114 pracowników personelu medycznego w tym: 48 (42\%) lekarzy oraz $66(58 \%)$ pielęgniarek. Średnia wieku badanych wynosiła $x=42,08 \pm 9,43$ lat, a średni staż pracy $x=17,16 \pm 10,36$ lat. Do badań wykorzystano autorski kwestionariusz ankiety dotyczący stosowania zasad ergonomii pracy, a do oceny występowania dolegliwości bólowych dolnego odcinka kręgosłupa standaryzowany Kwestionariusz Oswestry. Wyniki. W badanej grupie 95 osób $(83,33 \%)$, w tym 31 lekarzy $(64,58 \%)$ oraz 64 pielęgniarki $(96,96 \%)$ nie stosowało zasad ergonomii w środowisku pracy, a najczęstszym powodem był brak warunków do ich przestrzegania oraz niewystarczająca ilość personelu medycznego. Wszyscy badani doświadczyli występowania dolegliwości bólowych kregosłupa. Według Kwestionariusza Oswestry określono stopień niepełnosprawności wywołany bólem kręgosłupa. Wśród lekarzy największa część badanych $(\mathrm{n}=35 ; 73 \%)$ osiągnęła niewielki stopień niepełnosprawności spowodowany występowaniem dolegliwości bólowych kręgosłupa natomiast wśród pielęgniarek - mierny ( $\mathrm{n}=35$; 53\%). Wnioski. Zdecydowana większość badanych lekarzy i pielegniarek nie przestrzegała zasad ergonomii pracy i posiadała niepełna wiedze $\mathrm{w}$ tym zakresie. Wszyscy badani obarczeni byli występowaniem dolegliwości bólowych kręgosłupa, a co $10 \mathrm{z}$ nich w stopniu poważnym. Wyniki badań wskazują na potrzebę prowadzenia edukacji w zakresie ergonomii wśród pracowników personelu medycznego.

Słowa kluczowe: ergonomia pracy, ból dolnego odcinka kręgosłupa, kwestionariusz Oswestry

Address for correspondence / Adres korespondencyjny: Joanna Piotrkowicz, Department of Cardiology, School of Health Science in Katowice, Medical University of Silesia, Ziołowa 45/47, 40-635 Katowice, Poland, e-mail: joanna.piotrkowicz@gmail.com, phone: +48505 072509

ORCID: Joanna Piotrkowicz https://orcid.org/0000-0003-0996-7691, Zbigniew Gąsior https://orcid.org/0000-0003-3616-8932

Copyright: (C) Pope John Paul II State School of Higher Education in Biała Podlaska, Józefa Dąbek, Joanna Piotrkowicz, Dariusz Korzeń, Zbigniew Gąsior. This is an Open Access journal, all articles are distributed under the terms of the Creative Commons Attribution-NonCommercial-ShareAlike 4.0 International (CC BY-NC-SA 4.0) License (http://creativecommons.org/licenses/by-nc-sa/4.0/), allowing third parties to copy and redistribute the material in any medium or format and to remix, transform, and build upon the material, provided the original work is properly cited and states its license. 


\section{Introduction}

Medical professionals have a high risk for low back pain syndrome as a result of mechanical overload caused by prolonged standing, performing professional activities in a position of trunk flexion, extended time of working during surgery, and other duties.

Incorrect adjustment of a workstation and incorrect positioning for physical duties can lead to back pain and eventually even to disability.

Improper spinal movement can lead to back pain and a decrease the quality of life. This is a major social problem and a disease of civilization. Improper movement of the spine can even lead to degenerative lesions in the spine.

Incorrect posture during work (i.e. during diagnostic examination or taking care of patients) leads to overuse injuries of the spine, causing lumbosacral back pain and often referred pain due to a herniated nucleus pulposus putting pressure on neural roots [1].

This functional spinal disorder occurs when static and dynamic weight is more than the ability of the body to adapt bone and surrounding tissues. According to epidemiological data in well-developed countries, 40 to 60 percent of the population suffers back pain and about 30 percent of them have chronic back pain syndrome [2].

In medical professions it is typical to spend most of the time at work standing or moving dynamically. According to the estimated data, nurses and physicians spend an average of 16-24 percent of their working hours in standing or crouching positions with loaded and / or raised arms. During the 8-hour workday, they also walk about 4 to 7 kilometers. It is also common for these professionals to bend forward; this forward flexion is often accompanied by rotation of the spine in the transverse plane and lateral flexion in the frontal plane. This happens during nursing duties such as: getting patients up and putting them in the right posture, feeding, administering medications, and toilet needs. Each task can take from 30 seconds up to 15 minutes time [3-4]. There are also other risks for back pain such as: genetics, weakness of the joints, low levels of physical activity, trauma, other illness and lack of ergonomic movement patterns and incorrect adjustment of workstations [5-6].

Well-organized work conditions are the essential factor in providing a good quality of life for employees [7]. The field that takes care of these conditions and guides adjustments to workstations (keeping in mind both the goals of the work and the needs of the employee) is called work ergonomics. Ergonomics is the study of the interactions between people and objects, with the goal of making these interactions safer and more efficient [8].

Each workstation should be individually adjusted for the requirements and risk factors of the job associated with it. Working with good ergonomics helps to maintain or even improve the health of the employee and protects them from many illnesses such as: overload lesions, spine and joint arthritis, vision problems, headache and exhaustion [9].

\section{Aim of the study}

The main aim of the study was to assess the usage of ergonomics and the state of knowledge about ergonomics, as well as the incidence of back pain syndrome in the study group of nurses and physicians.

In addition, the study assessed the following questions:

1. Do the studied nurses and physicians adhere to principles of ergonomics?

2. When ergonomic principles were not used, what was the reason?

3. What level of disability due to low back pain were the nurses and physicians experiencing, according to the Oswestry Disability Index?

4. Are there differences between the examined physicians and nurses?

\section{Material and methods}

114 employed medical staff were examined, including 48 (42\%) physicians and 66 (58\%) nurses. There were $20(17.54 \%)$ people working on the surgical ward and $94(82.46 \%)$ on the non-surgical ward. Of the 114 respondents, 90 (78.94\%) were on duty, some of whom were in the ICU (27 respondents - 30\%). Average work experience was estimated to be $17.16 \pm 10.36$ years.

Inclusion criteria was: performing medical staff work as a physician or a nurse and work experience no less than 5 years. Exclusion criteria was lack of consent. Examination was carried out with an original questionnaire about ergonomics and the Oswestry Disability Index in Polish version for assessment of low back pain in the study group.

The original questionnaire consisted of two parts. The first was about general characteristics of the examined group including age, gender, Body Mass Index, height and detailed characteristics of their specific work. The 
second part consisted of questions about their knowledge of ergonomics and the practical usage of ergonomics principles. To assess the level of low back pain, the modified Oswestra Disability Index in Polish version was used. It contains questions about the influence of lower back pain on the functional state of living in categories such as: pain level, nursing, getting up, walking, sitting, standing, sleeping, social life, traveling and changing of pain intensity. Each criterion examined was assessed with questions that score between 0 and 5.

Examinees were grouped by level of disability based on the number of points they scored: inconsiderable (0-4 points), small (5-14 points), moderate (15-24 points), high (25-34) and total ( $>35$ points) [10-12].

Data was collected in a database and analyzed statistically with Statistica v.12.0. Descriptive statistics were gathered for the general characteristics of the examined group. To compare the data between the examined groups, the Student's t test and the Mann-Whitney U test were used, with the level of statistical significance at $\mathrm{p} \leq 0.05$.

\section{Results}

General characteristics of the studied group of physicians and nurses

General characteristics of the examined medical staff group, including age, weight, height and BMI are presented in Table 1.

Table 1. General characteristic of the studied group of medical personnel, including age, weight, height and BMI

\begin{tabular}{|c|c|c|c|c|c|}
\hline \multicolumn{6}{|c|}{ General characteristics of the studied group } \\
\hline & & General & Physicians & Nurses & \multirow{4}{*}{$\mathbf{p}$} \\
\hline Number of $g$ & $\%$ of group & $\mathrm{n}=114 ; 100 \%$ & $\mathrm{n}=48 ; 42 \%$ & $\mathrm{n}=66 ; 58 \%$ & \\
\hline \multirow{2}{*}{ Gender } & Women & $91 ; 79.82 \%$ & $27 ; 23.68 \%$ & $64 ; 56.14 \%$ & \\
\hline & Men & $23 ; 20.18 \%$ & $21 ; 18.42 \%$ & $2 ; 1.75 \%$ & \\
\hline \multicolumn{2}{|c|}{ Age [years] } & $x=42.08 \pm 9.43$ & $x=41.09 \pm 9.66$ & $x=43.56 \pm 9.21$ & 0.451 \\
\hline \multicolumn{2}{|c|}{ Body weight [kg] } & $x=68.45 \pm 13.37$ & $\mathrm{x}=70.09 \pm 13.34$ & $x=68.41 \pm 12.65$ & 0.267 \\
\hline \multicolumn{2}{|c|}{ Body height [m] } & $\mathrm{x}=1.68 \pm 0.08$ & $\mathrm{x}=1.66 \pm 0.07$ & $\mathrm{x}=1.72 \pm 1.12$ & 0.567 \\
\hline \multicolumn{2}{|c|}{ BMI $\left[\mathrm{kg} / \mathrm{m}^{2}\right]$} & $x=24.12 \pm 3.69$ & $x=24.16 \pm 3.57$ & $x=25.11 \pm 3.42$ & 0.148 \\
\hline \multicolumn{2}{|c|}{ Length of service } & $x=17.16 \pm 10.36$ & $x=15.67 \pm 10.11$ & $\mathrm{x}=18.78 \pm 14.89$ & $0.000^{*}$ \\
\hline
\end{tabular}

Abbreviations: $\mathrm{n}$ - number of group, $\mathrm{kg}$ - kilogram, $\mathrm{m}$ - meter, $\mathrm{p}$ - statistical significance $\left({ }^{*} \mathrm{p} \leq 0,05\right)$

Average physician work experience was $15.67 \pm 10.11$ years; this was statistically different from the nurses, whose average work experience was $18.78 \pm 14.89$ years.

Characteristics of the examined group, including specifics of their profession, are presented in Table 2.

Table 2. Characteristics of the studied group of medical personnel regarding profession and type of work

\begin{tabular}{|c|c|c|c|}
\hline \multicolumn{4}{|c|}{ Characteristics of the studied group of medical personnel regarding profession and type of work } \\
\hline Variable & General & Physicians & Nurses \\
\hline $\begin{array}{l}\text { Number of whole } \\
\text { group n; \% of group }\end{array}$ & $\mathrm{n}=114(100 \%)$ & $\mathrm{n}=48(42 \%)$ & $\mathrm{n}=66(58 \%)$ \\
\hline $\begin{array}{c}\text { Number of group } \mathrm{n} ; \% \\
\text { of group }\end{array}$ & $\mathrm{n}=114(100 \%)$ & $\mathrm{n}=48(100 \%)$ & $n=66(100 \%)$ \\
\hline \multicolumn{4}{|c|}{ Work on the surgical ward } \\
\hline Non-Surgical ward & $94(82.46 \%)$ & $39(81.25 \%)$ & $55(83.33 \%)$ \\
\hline Surgical ward & $20(17.54 \%)$ & $9(18.75 \%)$ & $11(16.67 \%)$ \\
\hline \multicolumn{4}{|c|}{ Duty } \\
\hline Yes & $90(78.94 \%)$ & $38(79.16 \%)$ & $52(78.78 \%)$ \\
\hline Acute duty & $27(30.00 \%)$ & $12(31.57 \%)$ & $15(28.85 \%)$ \\
\hline Non-acute duty & $63(70.00 \%)$ & $26(68.42 \%)$. & $37(71.15 \%)$ \\
\hline No & $24(21.06 \%)$ & $10(20.84 \%)$ & $14(21.22 \%)$ \\
\hline \multicolumn{4}{|c|}{$\begin{array}{l}\text { Is work a cause of high-stress? } \\
\end{array}$} \\
\hline Yes & $106(92.98 \%)$ & $44(91.66 \%)$ & $62(93.93 \%)$ \\
\hline No & $8(7.02 \%)$ & $4(8.34 \%)$ & $4(6.07 \%)$ \\
\hline
\end{tabular}

Abbreviation: $\mathrm{n}$ - number of group 
Out of the 114 examined medical staff members, most of them (n=94; 82.46\%) were doing their duty on the non-surgical ward and 106 (92.98\%) agreed that their job is high-stress.

On a 10 point scale, the average level of stress among examined persons was $6.08 \pm 2.40$; for physicians it was $5.71 \pm 2.36$ and for nurses it was $6.54 \pm 2.81$.

Characteristics of examined group of physicians and nurses, including usage of ergonomics principals and knowledge of ergonomics

Characteristics of the examined medical staff, including usage of ergonomics principals and knowledge about ergonomics are in Table 3. For this question, respondents could provide more than one answer.

Table 3. Characteristics of the studied group of medical personnel regarding knowledge of the definition of ergonomics

\begin{tabular}{|c|c|c|c|}
\hline \multicolumn{4}{|c|}{ Characteristics of the studied group regarding knowledge of ergonomics definition } \\
\hline Variable & General & Physicians & Nurses \\
\hline Number of whole group n; \% of group & $\mathrm{n}=114(100 \%)$ & $\mathrm{n}=48(42 \%)$ & $\mathrm{n}=66(58 \%)$ \\
\hline Number of group $\mathrm{n}$; \% of group & $\mathrm{n}=114(100 \%)$ & $\mathrm{n}=48(100 \%)$ & $\mathrm{n}=66(100 \%)$ \\
\hline Appropriate workplace organization & $77(67.54 \%)$ & $34(70.83 \%)$ & $43(65.15 \%)$ \\
\hline Taking proper body position during work activities & $67(58.77 \%)$ & $32(66.67 \%)$ & $35(53.03 \%)$ \\
\hline $\begin{array}{c}\text { Use of short breaks and exercises to regenerate the } \\
\text { body }\end{array}$ & $49(42.98 \%)$ & $26(54.17 \%)$ & $23(34.84 \%)$ \\
\hline Appropriate workplace equipment & $38(33.33 \%)$ & $24(50 \%)$ & $14(21.21 \%)$ \\
\hline
\end{tabular}

Abbreviation: $\mathrm{n}$ - number of group

This question gave different possible definitions of ergonomics, all of which were correct. Only 77 (67.54\%) of the 114 examined thought that work ergonomics is about the right organization of the workstation, and an even smaller proportion $(n=38 ; 33.33 \%)$ thought that it is about good equipment. Unfortunately, no one picked the whole correct answer for this question.

Characteristics of the examined group, including usage of the work environment, are in Table 4.

Table 4. Characteristics of the studied group of medical personnel regarding usage of ergonomics principles in the work environment

\begin{tabular}{|c|c|c|c|}
\hline \multicolumn{4}{|c|}{ Do the respondents respect the principles of ergonomics in the work environment? } \\
\hline Variable & General & Physicians & Nurses \\
\hline Number of whole group $\mathrm{n}$; \% of group & $\mathrm{n}=114(100 \%)$ & $\mathrm{n}=48(42 \%)$ & $\mathrm{n}=66(58 \%)$ \\
\hline Number of group n; \% of group & $\mathrm{n}=114(100 \%)$ & $\mathrm{n}=48(100 \%)$ & $\mathrm{n}=66(100 \%)$ \\
\hline Yes & $19(16.67 \%)$ & $17(35.41 \%)$ & $2(3.03 \%)$ \\
\hline No & $95(83.33 \%)$ & $31(64.58 \%)$ & $64(96.96 \%)$ \\
\hline \multicolumn{4}{|c|}{ Why do the respondents not respect the principles of ergonomics in the work environment? } \\
\hline Variable & General & Physicians & Nurses \\
\hline Number of whole group $\mathrm{n}$; \% of group & $\mathrm{n}=114(100 \%)$ & $\mathrm{n}=48(42 \%)$ & $\mathrm{n}=66(58 \%)$ \\
\hline Number of group $\mathbf{n} ; \%$ of group & $\mathrm{n}=114(100 \%)$ & $\mathrm{n}=48(100 \%)$ & $\mathrm{n}=66(100 \%)$ \\
\hline $\begin{array}{l}\text { Lack of conditions in the work environment to } \\
\text { comply with the principles of ergonomics }\end{array}$ & $81(71.05 \%)$ & $21(43.75 \%)$ & $60(90.90 \%)$ \\
\hline Insufficient number of medical personnel & $54(47.36 \%)$ & $16(33.33 \%)$ & $38(57.57 \%)$ \\
\hline Lack of proper adaptation of premises & $33(28.94 \%)$ & $8(16.67 \%)$ & $25(37.87 \%)$ \\
\hline $\begin{array}{c}\text { Excess of duties } \\
\end{array}$ & $42(36.84 \%)$ & $7(14.58 \%)$ & $35(53.03 \%)$ \\
\hline Habits & $18(15.78 \%)$ & $8(16.67 \%)$ & $10(15.15 \%)$ \\
\hline
\end{tabular}

Abbreviation: $\mathrm{n}$ - number of group

The majority of those examined ( $n=95 ; 83.33 \%)$ admitted that they do not use ergonomics principals at their workstation. The main reasons they reported were no ability to use ergonomics in their work $(\mathrm{n}=81 ; 71.05 \%)$ and not enough medical staff to make ergonomic activity possible ( $n=54 ; 47.36 \%)$. 
Characteristics of the examined group of physicians and nurses, including the occurrence of low back pain in daily life according to the Oswestry Disability Index

Characteristics of the examined group of physicians and nurses, including the occurrence of back pain and its interference with daily life, are presented in Table 5.

Table 5. Characteristics of the studied group regarding occurrence of low back pain syndrome based on the Oswestry Questionnaire

\begin{tabular}{|c|c|c|c|c|}
\hline \multicolumn{5}{|c|}{ Intensity of low back pain according to the Oswestry Questionnaire } \\
\hline Variable & General & Physicians & Nurses & \\
\hline $\begin{array}{l}\text { Number of whole group } \mathrm{n} ; \\
\% \text { of group }\end{array}$ & $\mathrm{n}=114(100 \%)$ & $\mathrm{n}=48(42 \%)$ & $\mathrm{n}=66(58 \%)$ & p \\
\hline Intensity of pain & $x=2.32 \pm 1.43$ & $x=2.09 \pm 1.40$ & $x=2.45 \pm 1.62$ & $0.000^{*}$ \\
\hline Lifting & $x=2.28 \pm 1.53$ & $x=1.31 \pm 1.53$ & $x=2.96 \pm 1.65$ & $0.000^{*}$ \\
\hline Sitting & $\mathrm{x}=1.95 \pm 1.00$ & $\mathrm{x}=1.76 \pm 0.95$ & $x=2.08 \pm 1.17$ & $0.000^{*}$ \\
\hline Sleeping & $\mathrm{x}=1.58 \pm 0.78$ & $\mathrm{x}=1.42 \pm 0.74$ & $x=1.78 \pm 0.56$ & 0.542 \\
\hline Traveling & $x=1.85 \pm 0.92$ & $x=1.67 \pm 0.86$ & $x=1.99 \pm 0.98$ & 0.232 \\
\hline Care & $x=1.37 \pm 0.77$ & $x=1.22 \pm 0.59$ & $x=1.47 \pm 0.62$ & 0.564 \\
\hline Walking & $x=1.29 \pm 0.65$ & $x=1.21 \pm 0.54$ & $x=1.33 \pm 0.71$ & 0.321 \\
\hline Standing & $x=2.04 \pm 1.06$ & $x=1.89 \pm 1.06$ & $x=2.12 \pm 1.09$ & $0.000^{*}$ \\
\hline Social life & $x=1.37 \pm 0.75$ & $x=1.27 \pm 0.62$ & $x=1.46 \pm 0.88$ & 0.552 \\
\hline Changes of pain intensity & $x=1.69 \pm 0.85$ & $x=1.51 \pm 0.74$ & $x=1.89 \pm 0.91$ & 0.535 \\
\hline SUM & $x=15.56 \pm 6.08$ & $x=14.04 \pm 5.29$ & $x=17.29 \pm 7.01$ & $0.000^{*}$ \\
\hline
\end{tabular}

Abbreviation: n-number of group, p-statistical significance $\left({ }^{*} \mathrm{p} \leq 0.05\right)$

On the Oswestry Disability Index, the average number of points (on a scale from 0 to 50 ), was 15.56, with results of 14.04 for physicians and 17.29 for nurses. There were observed statistically significant differences in categories such as: pain level, getting up, sitting, standing, and the total amount of points between examined physicians and nurses.

Figure 1. shows characteristics of the examined medical staff, including the state of disability caused by the low back pain according to the Oswestry Disability Index.

\section{The degree of disability caused by low back pain \\ in the studied group \\ $\mathrm{n}=114 ; 100 \%$}

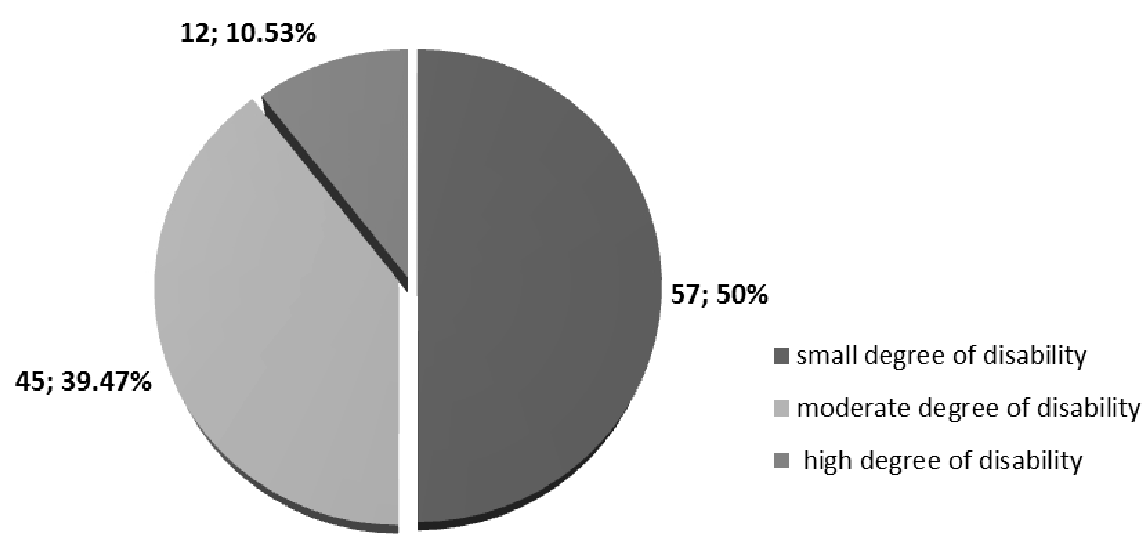

Figure 1. Characteristic of the studied group of medical personnel regarding the degree of disability caused by low back pain

According to the point score on the Oswestry Disability Index, there were different levels of disability caused by low back pain. Minimal disability was seen in 57 of those examined (50\%), medium disability in 45 of those examined (39.47\%), and serious disability in 12 (10.53\%) of examined persons. 
Figure 2. shows the characteristics of the examined group including the state of disability (ODI), depending on the type of profession.

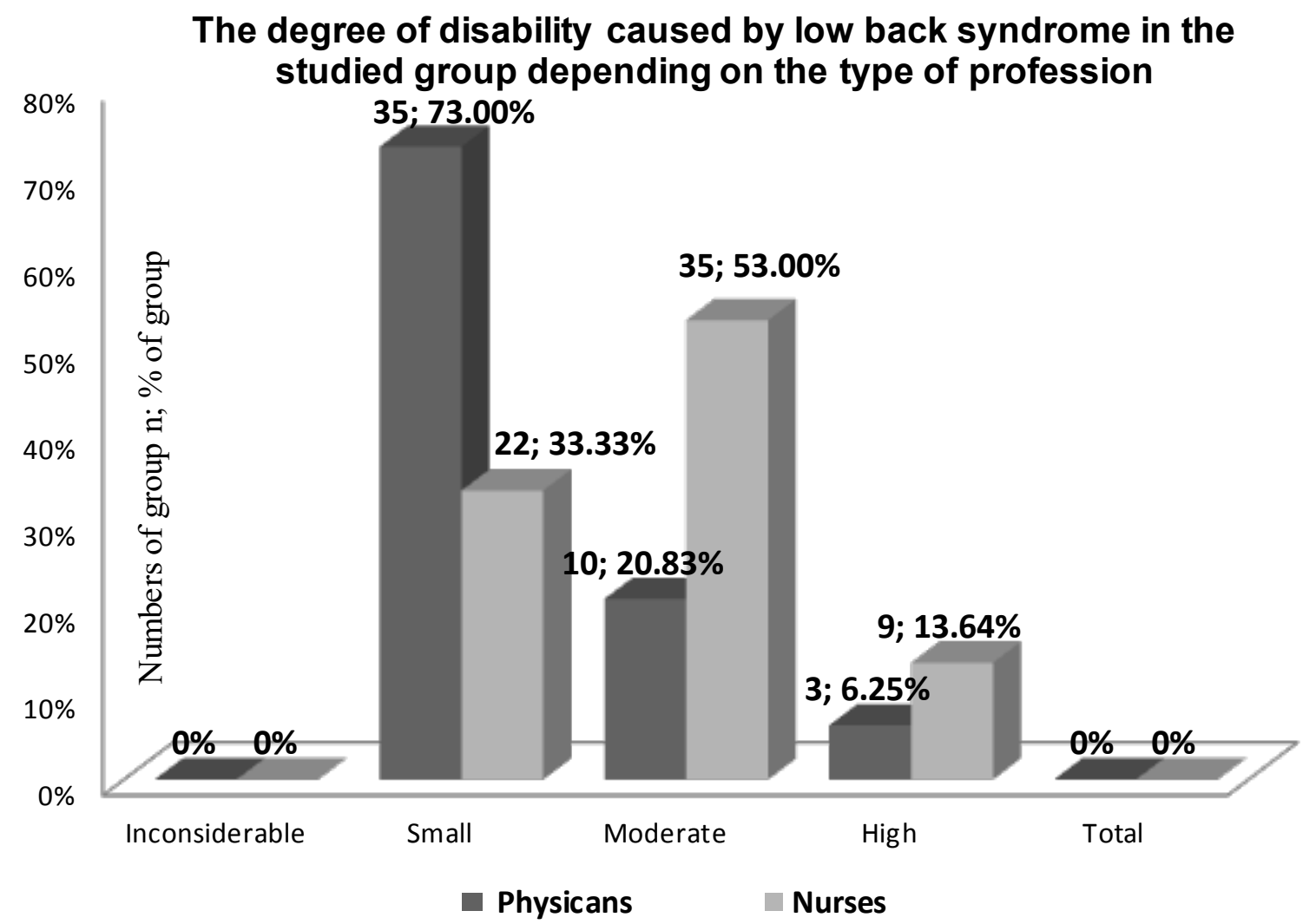

Figure 2. Characteristic of the studied group of medical personnel regarding the degree of disability caused by low back pain depending of the type of profession

Most of the examined physicians $(n=35 ; 73 \%)$ had minimal disability caused by back pain; most nurses had a medium level of disability $(n=35 ; 53 \%)$.

\section{Discussion}

Specifics of medical staff work may predispose to higher risk of back pain. According to Maciuk and coworkers, the frequency of lumbosacral spine pain among nurses is about $75 \%$, and for cervical spine pain it is $60 \%$ and increasing [3]. The most common reason for back pain is mechanical factors. Improper positioning and movement of the torso (dynamic and static) leads to overuse of the spine structures which leads to overload syndrome or degenerative lesions or even disability.

Kułagowska et al. stated that $97 \%$ of nurses working on long-term care units suffer from back pain, of which $82 \%$ is in the lumbosacral spine [1]. Those results are similar to this study, in which every person asked admitted that they had a problem with back pain.

In the Kułagowska et al. study, the examined nurses proposed changes that could decrease the pain and injuries caused by their jobs such as: more employees (82\%), using helpful medical equipment (53\%), architectural changes (36\%) and changes in work organization (26\%).

Similar results were observed in this study in which the examined professionals described the problem as: not enough staff (47.36\%), no opportunity to use principals of ergonomics during their work (71.05\%) and improper adjustment of their workstation (28.94\%). The data suggests that increasing the amount of medical staff on the ward and better adjustment of the workstations could improve work conditions by making it possible to use ergonomics, which leads to decreasing the overuse of the body and decreasing the back pain.

Burdof et al. and Koppelar et al. checked PubMed and Embase or Web of Science and showed that moving patients causes back pain. They proved that elimination of this movement decreases back pain. This suggests that correct adjustment of the workstation and equipping the wards with helpful medical equipment, such as lifts, will improve the working conditions for the medical staff [13-14]. 
Pop and co-workers assessed the severity of back pain with the Oswestry Disability Index among medical staff, including doctors, nurses and physiotherapists. 90\% of the examined group suffered from lumbosacral spine pain back pain, and $19 \%$ of them had no disability $(n=32)$ but $1 \%(n=2)$ had total disability caused by back pain.

They also assessed the level of disability according their jobs. $12 \%(n=13)$ of nurses and 29\% ( $n=9)$ of doctors had no disability. 45\% (n=49) of nurses and 55\% (n=17) of doctors had minimal disability, 34\% (n=37) of nurses and $13 \%(n=4)$ of doctors had medium disability and $7 \%(n=8)$ of nurses and $3 \%(n=1)$ of doctors had serious disability, and $1 \%(n=1)$ of nurses had total disability caused by back pain. They also proved that the level of characteristics of ward "hard" or "soft" does not make a difference for a level of illness caused by back pain [15].

Similar results were found in our current study; therefore we have to consider that there is a difference between the level of disability due to back pain between examined doctors and nurses as measured by the ODI. Most of the doctors had a low level of disability, but most of the nurses had a medium level of disability. This suggests that nurses are more likely to be injured or develop back pain by doing their duty than are doctors.

Radzimińska et al. also analyzed back pain among the nurses; they had very similar results to this study. The average score on the ODI was 16.33. In that study $65 \%(n=39)$ of persons had $5-14$ points, which indicates a low level of disability caused by the back pain. Only 7 people (11.66\%) had no disability (0-4 points) but 5 of them (8.33\%) had serious disability (25-34 points). This is similar to this current study, in which most examinees (50\%) had minimal disability and $10.53 \%$ had severe disability caused by back pain according to the ODI [16].

In analyzing the results of the ODI, we observed that the examined medical staff had statistically important differences in categories such as: intensity of pain, lifting, sitting, standing, and the total amount of points. The average of each of these categories was higher for nurses than for doctors. According to this data we can assume that nurses are at the higher risk for back pain than doctors.

Data about back pain in medical staff has been gathered for a long time and we can observe the increased tendency to develop back pain when we look at this data. Therefore, studies about the prevention of back pain among medical staff may prove that ergonomics education will improve their health quality and decrease the incidence of back pain [17-18].

\section{Conclusions}

1. The majority of examined doctors and nurses did not use ergonomics and their knowledge about ergonomics was not adequate.

2. All the examined persons were having back pain and one of every ten of them had a serious problem with it.

3. It was observed that most of the physicians have had a low disability score but nurses had mainly medium levels of disability, which suggests that they have more taxing work.

4. The results we got suggest education of medical staff about ergonomics and enforcement of rules for using ergonomics.

\section{References:}

1. Kułagowska E, Kosińska M, Karolak I. [Safety and ergonomics in the work of long-term care nurses]. Zeszyty Naukowe Małopolskiej Wyższej Szkoły Ekonomicznej w Tarnowie. 2017; 3(35): 79-91 (in Polish).

2. Dziak A. [Pain dysfunctions of the lumbar spine. ABC of orthopedics, traumatology and rehabilitation]. Medicina Sportiva. 2005; 9: 323-344 (in Polish).

3. Maciuk M, Krajewska-KulakE, Klimaszewska K. [Self-assessment of low back pain incidence in professionally active nurses]. Prob Hig Epidemiol. 2012; 93(4): 728-738 (in Polish).

4. Dobrowolna P, Hagner W. [Epidemiology of spinal pain syndrome in nurses at the A. Jurasz University Hospital in Bydgoszcz and biomechanical analysis of the problem]. Medical and Biological Sciences. 2007; 21(4): 53-63 (in Polish).

5. Juraszek K, Hagner-Derengowska M, Hoffmann M, Kalisz Z, Zukow W. The impact of work on the occurrence of back pains on the example of nurses in the Kujawsko-Pomorskie voievodeship. Journal of Education, Health and Sport. 2016; 6(8): 504-521. https://doi.org/10.5281/zenodo.60944

6. Bilski B. [Occupational health in nursing]. Poznań: Uniwersytet Medyczny im. Karola Marcinkowskiego w Poznaniu; 2009 (in Polish).

7. Polek-Duraj K. [The quality of work as a determinant of quality of society life (case study)]. Studia Ekonomiczne. 2017; 309: 133-142 (in Polish). 
8. World Health Organization. [The European health report 2012. Charting the way to well-being]. Kopenhaga: World Health Organization; 2013 (in Polish).

9. Kanteluk AA, Krajewska-Kułak E, Fiłon J. [Implementation of selected ergonomic principles in everyday life as viewed by nursing and chemistry students - preliminary report]. Probl Hig Epidemiol. 2015; 96(1): 269278 (in Polish).

10. Antczak A, Haor B, Głowacka M, Biercewicz M. [Quality of life in patients with lumbar spine pain after sanatorium treatment - preliminary reports]. Piel Zdr Pub. 2014; 4(1): 19-25 (in Polish).

11. Czenczek-Lewandowska E, Przysada G, Brotoń K, Leszczak J, Rykała J, Podgórska-Bednarz J. [The influence of rehabilitation on the functional status and pain in patients with spinal overload syndrome]. Przegląd Medyczny Uniwersytetu Rzeszowskiego i Narodowego Instytutu Leków w Warszawie. 2014; (3): 243-252 (in Polish).

12. Jabłońska R, Królikowska A, Ślusarz R. [The use of Repty Functional Index and Oswestry Disability Questionnaire for the functional evaluation of the patients treated surgically because of intervertebral disc damage]. Pielęgniarstwo Neurologiczne i Neurochirurgiczne. 2014; 3(2): 64-74 (in Polish). https://doi.org/10.15225/PNN.2014.3.2.3

13. Budorf A, Koppelaar E, Evanoff B. Assessment of the impact of lifting device use on low back pain and musculoskeletal injury claims among nurses. Occup Environ Med. 2013; 70(7): 491-497. https://doi.org/10.1136/oemed-2012-101210

14. Koppelaar E, Knibbe HJ, Miedema HS, Burdorf A. The influence of ergonomic devices on mechanical load during patient handling activities in nursing homes. Ann Occup Hyg. 2012; 56(6): 708-718. https://doi.org/10.1093/annhyg/mes009

15. Pop T, Przysada G, Świder B. [Disability degree of medical personnel measured by Oswestra Questionnaire]. Prz Med Uniw Rzesz. 2008; 2: 135-141 (in Polish).

16. Baumgart M, Radzimińska A, Szpinda M, Kurzyński P, Goch A, Zukow W. Spinal pain among nurses. Journal of Education, Health and Sport. 2015; 5(9): 633-646. https://doi.org/10.5281/zenodo.31735

17. Zhang CH, Hsu L, Zou BR, Li JF, Wang HY, Huang J. Effects of a pain education program on nurses pain knowledge, attitudes and pain assessment practices in China. J Pain Symptom Manage. 2008; 36(6): 616-27. https://doi.org/10.1016/j.jpainsymman.2007.12.020

18. Jaromi M, Nemeth A, Kranicz J, Laczko T, Betlehem J. Treatment and ergonomics training of work-related lower back pain and body posture problems for nurses. J Clin Nurs. 2012; 21(11-12): 1776-84.

https://doi.org/10.13075/mp.5893.00225 